\title{
ПСИХОЛОГІЧНЕ ЗДОРОВ'Я І ПСИХОЛОГІЧНЕ БЛАГОПОЛУЧЧЯ ОСОБИСТОСТІ ЯК СКЛАДОВІ ЗАДОВОЛЕНОСТІ ЖИТТЯМ
}

УДК: 159.91:[316.613:304]

\section{Кашлюк Юліанна Ігорівна}

Аспірант кафедри психології філософського факультету Львівського національного університету імені Івана Франка, м. Львів (Украӥна)

\begin{abstract}
Анотація. Стаття присвячена проблемі психологічного здоров'я, яке на сьогоднішній день є значимим об'єктом дослідження багатьох наук в тому числі психології, де показники психологічного здоров'я розглядаються як кумулятивні індикатори рівня благополуччя (якості життя) людей, суспільства в циілому та окремих його складових. Дане поняття тісно пов'язане $з$ поняттям психологічного благополуччя, щзо є одним з основних елементів психологічного буття особистості.

У статті розглянуто основні теоритичні підходи до розуміння понять «психологічне здоров'я» та «психологічне благополуччя» особи. Розкрито сутність та напрями їх дослідження в сучасній психологічній науці. Проаналізовано взаємозв'язок психологічного здоров'я, психологічного благополуччя в контексті суб 'єктивної оцінки якості життя.
\end{abstract}

Ключові слова: здоров'я, психологічне здоров'я, психологічне благополуччя, критерії психологічного здоров'я, здоровий спосіб життя.

\section{Постановка проблеми та ії зв'язок 3} важливими практичними завданнями. Проблема психологічного здоров'я привертає увагу багатьох дослідників різних галузей науки i практики: філософів, медиків, педагогів, соціологів, психологів та ін. Водночас є підстави для твердження про недостатню їі дослідженість у психології і пов'язано це з багатоаспектністю даного феномена. В усталеному розумінні психологічне здоров'я асоціюється із станом нашого тіла, психіки і соціального оточення, i, згідно з даними ВООЗ, має місце наявність певних структурно-функціональних характеристик організму та стану його емоційного й соціального благополуччя [4, с. 214].

Розуміння феномена «психологічного здоров'я» вимагає розкриття його сутності та детермінант. Зважаючи на це, одним із головних підходів до вирішення проблеми є розгляд iii в контексті таких понять як «самоактуалізація особистості», «особистісна 
зрілість», «автентичність» та ін. Встановити причиново-наслідкові зв'язки між феноменами «психологічне благополуччя» та «психологічне здоров'я» - є одне з найважливіших завдань дослідників на сьогоднішній день.

Таким чином, вивчення психологічного благополуччя особистості та його складових дає змогу краще зрозуміти роль психологічного здоров'я (якщо розглядати здоров'я як складову благополуччя), його умов і чинників (якщо розглядати здорову особистість) як таку, що самоактуалізується і є зрілою, автентичною, успішною у різних сферах.

Аналіз останніх досліджень та публікацій.

Історично склалося так, що в наукову літературу поняття «психологічне здоров'я особистості» введено порівняно недавно, підтвердженням цього $є$ те, що лише словник за редакцією А. Петровського та М. Ярошевського (1990р.) трактує даний феномен, як: «стан душевного благополуччя, що характеризується відсутністю хворобливих психічних явищ і забезпечує адекватну умовам навколишньої дійсності регуляцію поведінки і діяльності» [3, с. 316].

Актуальність феномену психологічного здоров'я в наукових колах української науки підтверджено дослідженнями М. Боришевського, Г. Ложкіна, С. Максименка, T. Піроженко, проте, як теоретичні так i експериментальні дослідження $є$ незавер- шеними. В подальшому дана проблема досліджувалась у різних аспектах і привертала увагу таких дослідників як: М. Амосова, Г. Апанасенко, I. Брехмана, Д. Венедиктова, О. Ізуткіна, Л. Попова, А. Царенко та ін.; здорову особистість вивчали: О. Богініч, Е. Вільчковський, Л. Волков, Н. Денисенко, О. Дубогай, Л. Сварковська та ін.; роль фізичного здоров'я - I. Бех, В. Котирло, С. Кулачківська, С. Ладивір, Р. Павелків, Т. Піроженко та ін.; питання психічного здоров'я - Л. Артемова, А. Богуш, О. Кононко, Т. Поніманська та ін.; питання соціального здоров'я - О. Байєр, О. Вовчик-Блакитна, O. Запорожець, I. Корнієнко, С. Кулачківська, С. Лазаревич та ін. [2, с. 332-339].

Пізніше дослідження даного феномену зосереджується на деяких аспектах фенемену. Так, О. Алексєєв розглядав настрій і здоров'я; М. Боришевський - психологію самоактивності та суб'єктного розвитку особистості як саморегульованої соціальнопсихологічної системи; Б. Братусь - аномалії особистості; I. Дубровіна - психологічне здоров'я учасників освітнього процесу; Л. Дьоміна, I. Ральникова - психічне здоров'я та захисні механізми особистості; Г. Ложкін, М. Мушкевич, О. Наскова, І. Толкуновапсихологія здоров'я людини; С. Максименко - генетичну психологію; В. Панкратовсаморегуляцію психічного здоров'я; Д. Федотов - збереження психічного здоров'я; 
О. Хухлаєва - особливості психічного здоров'я студентів; та інші. [2, с. 332-339].

Одночасно 3 дослідженням феномену психологічного здоров'я, активно і різнобічно в психології та інших науках досліджується психологічне благополуччя особистості, вивчення якого має глибокі історичні корені. В науковий обіг дане поняття увійшло в минулому столітті i обумовлено появою «позитивної психології» як нової течії в науці.

Теоретичну базу для обгрунтування феномена «психологічного благополуччя» та його ролі в самореалізації та самоактуалізації особистості заклали дослідження К. Ріфф, Н. Бредберн, М. Аргайл та ін., де психологічне благополуччя особистості включено ними в поняття «щастя», «задоволеність життям» та «психологічне здоров'я» i т.д. М. Аргайл у своїй роботі «Психологія щастя» використовує поняття «психологічне благополуччя», оскільки «щастя можна розглядати як усвідомлення своєї задоволеності життям або як частоту та інтенсивність позитивних емоцій» [5, с. 95-129].

Постановка завдання. Теоретичний аналіз наукової літератури, присвяченої дослідженню проблеми психологічного здоров'я та психологічного благополуччя особистості; визначення критеріїв психологічного здоров'я; взаємозв'язок психологічного здоров'я та психологічного благополуччя, в контексті суб’єктивної якості життя, задоволеності життям.

\section{Виклад основного матеріалу дослі-} дження. Поняття феномена «психологічне благополуччя особистості» розглядається як системна якість людини, що набувається нею у процесі життєдіяльності та виявляється в переживанні смислової наповненості свого життя і дозволяє актуалізувати свої індивідуально-психологічні можливості для досягнення внутрішніх, соціально орієнтованих цілей (А. Вороніна, В. Пахальян).

Даний феномен являє собою складне багатофакторне особистісне утворення, що включає згідно тверджень К. Ріфф ряд компонентів: автономність (здатність бути незалежним, протистояти соціальному тиску і оцінювати себе виходячи 3 власних стандартів); самоприйняття (позитивне ставлення до себе і свого минулого); особистісний picm (сприйняття свого життя як процесу самореалізації); мета в житті (переживання осмисленості життя, наявність занять, що додають життю сенсу); компетентність (успішне управління навколишнім середовищем, здатність домагатися бажаного); позитивні відносини з іншими (здатність бути відкритим спілкуванню і ставитися до інших людей тепло, з турботою і довірою).

Н. Бредберн, М. Аргайл охарактеризували психологічне благополуччя як переживання щастя і задоволеності життям, як переважання позитивних емоцій над негативними, а також інтенсивність вираженості позитивних емоцій. 
Сучасне розуміння феномену психологічного благополуччя особистості базується на теоріях та концепціях, а саме: особистісного зростання (А. Адлер), особистісної зрілості (К. Роджерс), суб'єктності, самоактуалізації, внутрішньої мо-тивації, прояв справжнього «Я» ( А. Маслоу), гармонійності особистості (Г. Олпорт, Д. Леонтьєв). В той же час, варто відзначити, що дослідження поглиблюються і розширюються, 3'являються спроби виділити найваж-ливіші чинники і факторну структуру простору змінних компонентів [6, с. 486-500].

I підтвердженням цього є спроба Е. Дінера виокремити двохфакторну (суб'єктивне благополуччя і відкритість досвіду, яка розглядається як показник самоактуалізації) та трьохфакторну (суб'єктивне благополуччя, особистісне зро-стання і релігійність) моделі благополуччя. Віттерс Дж. виокремив детермінанти благополуччя, а саме: отримання задоволення (насамперед, задоволення базових потреб) та наявність внутрішньої мотивації. [7, с. 229-331].

Поняття «психологічне благополуччя» особистості Г. Ложкін, Д. Леонтьєв, Б. Братусь ототожнюють 3 цілим рядом близьких за значенням понять: «психічне здоров'я», «позитивний стиль життя», «емоційний комфорт», «якість життя», «задоволеність життям», тощо. Найчастіше зазначені поняття асоціюються ними 3 поняттям «психологічне здоров’я».

Іноді виникає непорозуміння в тракту- ванні змісту понять «психічне здоров'я» та «психологічне здоров'я» і тут варто зробити чітке розмежування. Якщо в понятті «психічне здоров'я» підкреслюється альтернатива психічному нездоров'ю, тобто порушення психіки, психічні захворювання, а також низька життездатність індивіда (H. Бредберн), то «психологічне здоров'я» являє собою комплексну характеристику особистості, що має структуру і динаміку, визначений соціокультурний феномен, що передбачає повноту іiі духовного розвитку.

3. Фрейд один із перших вивчав проблеми психологічного здоров'я. Він вважав, що весь спектр негативних емоційних переживань (депресія, тривожність та ін.) - суб'єктивна сторона конфліктів, що виникають при неузгодженості цілей і засобів їх досягнення, які ставить перед собою людина, і зрозумів, що багато психічних порушень, $є$ наслідком внутрішньо-особистісних конфліктів, які мають місце навіть у здорових людей.

А. Маслоу підкреслював, що люди, здорові в психологічному сенсі - це люди 3 високим ступенем самоактуалізації, а саме психологічне здоров'я це здатність особистості до самореалізації, самоактуалізації.

А. Адлер, Е. Фромм вважали якість міжособистісних стосунків як важливий показник психічного та психологічного здоров'я.

Р. Ассаджолі описує психологічне здоров'я як баланс між різними аспектами особи- 
стості; С. Фрайберг - між потребами індивіда та суспільства.

О. Хухлаєва, Г. Нікіфоров, наші вітчизняні психологи, розуміють психологічне здоров'я як динамічну рівновагу між індивідом та середовищем та асоціюють його зі стійкістю до стресу, гармонією та духовністю.

I. Дубровіна визначає психічне здоров'я як нормальне функціонування окремих психічних процесів, а психологічне здоров'я відносить до особистості в цілому, до прояву людського духу та вважає, що саме психологічне здоров'я робить особистість самодостатньою.

Б. Братусь, М. Михайлина, В. Слободчиков, пов'язують психічне та психологічне здоров'я особистості 3 такими характеристиками, як здатність пристосовуватись до соціального та природного оточення, стресостійкість і стабільність в процесі активної взаємодії з середовищем, включеність в співтовариство, відповідність певним соціальним і культурним вимогам [3, с. 316].

Всесвітня організація охорони здоров'я запропонувала використовувати поняття «благополуччя» як основний показник здоров'я. Значна частина психологів замість поняття «психологічне здоров'я» використовують поняття «психологічне благополуччя».

Здоров'я є базовим феноменом благополуччя людини. Тобто, здоров'я особистості - це не лише відсутність хвороб, а й утверджене благополуччя. Здорова особис- тість - це активна особа у всіх особистісних проявах (тілесне, соціальне, емоційне, когнітивне та ін.), а благополуччя є додатковою якістю, основне призначення якої - забезпечення гармонізації у зазначених напрямках розвитку. Психологічне здоров'я має тісний зв'язок з індивідуальними особливостями особистості, що інтегрує у всі аспекти внутрішнього світу і проявляє себе як єдине ціле [1, с. 89-122].

3 феноменами «психологічне здоров'я», «особистісне здоров'я», «особистісна зрілість» узгоджується поняття «особистісний потенціал», введене і досліджене Д. Леонтьєвим. Дане поняття інтерпретується ним як «інтегральна системна характеристика індивідуально-психологічних особливостей особистості, що лежить в основі здатності виходити у своїй життєдіяльності із стійких внутрішніх критеріїв та орієнтирів i зберігати стабільність смислових орієнтації та ефективність діяльності на тлі тисків і змінних зовнішніх умов». По суті, це вищий рівень розвитку особистості, здатність людини проявляти себе як особистість, це відображення потенціалу саморегуляції життєдіяльності. Особистісній потенціал, згідно 3 твердженням Д. Леонтьєва включає три регуляторні функції: функиія самовизначення - вибір мотивів $\mathrm{i}$ цілей для досягнення, розкриття потенціалу свободи; функиія реалізації - здійснення задуманого, подолання невизначеності і розкриття потенціалу відповідальності; функція збере- 
ження - гнучкість перед стресогенними і деформуючими впливами. Таке розуміння зумовлює можливість розглядати структуру та зміст психічного і психологічного здоров'я, їх критерії, умови формування та збереження.

Окремі автори, зокрема I. Галецька, пропонують двофакторну структуру псіхічного здоров'я: структурно-процесуальне психічне здоров'я і окремо - психологічне здоров'я. Структурно-процесуальне психічне здоров'я, згідно трактування, стосується психічної діяльності, характеристик процесів та властивостей когнітивної й емоційно-вольової сфер. В той же час, психологічне здоров'я - $\epsilon$ втіленням соціального, емоційного та духовного благополуччя (як ресурсу та стану), оскільки є потенційною передумовою забезпечення життєвих потреб щодо активного способу життя, досягнення власних цілей, адекватної й оптимальної взаємодії із людьми. Психологічне здоров'я стосується семантичних аспектів, властивостей «Я» і охоплює сутнісні властивості ціннісно-мотиваційної та ноогенної сфер людини [1, с. 89-122].

Переконливою є концепція Б. Братуся, який обгрунтовує проблему нормального й аномального психічного розвитку та визначає психічне здоров'я, як складне утворення. Він акцентує, що психічне здоров'я має три рівні відповідно до рівнів функціонування психічного апарату:
1) особистісно-смисловий рівень, або рівень особистісного здоров'я, який визначається якістю смислових відношень;

2) рівень індивідуально-психологічного здоров'я, оцінка якого залежить від здатності людини вибудовувати адекватні смислові прагнення;

3) рівень психофізіологічного здоров'я, який визначається особливостями внутрішньмозкової, нейрофізіологічної організації актів психічної діяльності.

Кожен із цих рівнів, акцентує Б. Братусь, має як свої критерії, так і особливі закономірності протікання. Психофізіологічний рівень безпосередньо пов'язаний зі спадковими біологічними характеристиками, інші два$\epsilon$ власне психологічними рівнями, які залежать від соціальних умов, навчання та виховання.

Н. Гончаренко обгрунтовує своє бачення, вона основні прояви здорової психіки, співвідносить відповідно до форм прояву психічного (психічні стани, процеси, властивості, ступінь саморегуляції та ін.), і дає розгорнуту деференціацію критеріїв психічного здоров'я $\mathrm{i}$ відзначає:

- серед властивостей особистості: оптимізм, зосередженість, урівноваженість, етичність, адекватний рівень вимог (домагань), почуття обов'язку, впевненість у собі, невразливість до образ (уміння позбавлятися образ), працелюбство (не лінивість), незалежність, безпосередність (природність), відповідаль- 
ність, почуття гумору, доброзичливість, терпимість, самоповага, самоконтроль;

- серед психічних станів: стійкість, зрілість почуттів, володіння негативними емоціями (страх, гнів, жадоба, заздрість та ін.), вільний природний прояв почуттів та емоцій, здатність радіти, збереження звичного оптимального самопочуття;

- серед психічних процесів: адекватне сприйняття самого себе; здатність до логічної обробки інформації; критичність мислення; креативність; знання себе; дисципліна розуму (управління думками). [2, с. 332-339].

Л. Сварковська в психічне здоров'я включає такі критерії: адаптивність, соціальна рівновага, відчуття благополуччя , гармонійність розвитку організму та його здатність функціонувати [1, с. 89-122].

А. Афашагова, зосереджує свою увагу на більш глибокому аналізі розуміння критерію «відчуття благополуччя» $\mathrm{i}$ розглядає його як соціально-педагогічну категорію, головною ознакою якої $є$ триєдиність почуття благополуччя: фізичного, психічного, емоційного.

Аналогічне трактування знаходимо в В. Канепа, Б. Ольшанського i Г. Цареградцева: «Здоров’я - це не тільки одна з необхідних передумов щастя людини, iii всебічного, гармонійного розвитку. Воно $\epsilon$ також важливим показником i чутливим індикатором благополуччя людей» [3, с. 316].
Дослідження даної проблеми, дає підстави ще раз звернутись до думки представників позитивної психології, які «здоров'я» розуміли як «благополуччя». Даний феномен вони трактували як багатофакторний конструкт, що являє собою складний взаємозв'язок культурних, соціальних, психологічних, фізичних, економічних, духовних факторів та залежить від впливу генетичної схильності, середовища та особливостей індивідуального розвитку.

Відповідно, модель психологічного здоров'я, може включає такі компоненти:

1. Аксіологічний компонент - усвідомлення людиною своєї цінності і унікальності, а також цінності і унікальності оточуючих. Особа повністю приймає саму себе і при цьому визнає цінність і унікальність оточуючих людей. 2. Інструментальний компонент - володіння рефлексією як засобом самопізнання, здатністю концентрувати свідомість на самому собі, своєму внутрішньому світі і своєму місці у взаєминах з іншими.

3. Потребо-мотиваційний компонент - наявність у людини потреби в саморозвитку, тобто в особистісному зростанні. Людина повністю приймає відповідальність за своє життя. 4. Розвивальний компонент- наявність динаміки в розумовому, особистісному, соціальному, фізичному розвитку себе та інших людей. 5. Соціокультурний компонент- можливість успішно діяти, розвиватися в оточуючих соці- 
ально-культурних умовах, розуміти і взаємодіяти з людьми [1, с. 89-122].

Отже, в дослідженнях науковців, простежується подібність в трактуванні понять «здоров’я» та «благополуччя», а іноді і взаємозаміна їх і на це є підстави:

по-перше, обидва твердження розглядаються як комплексні, багатоаспектні феномени, що базуються на різного роду складових: фізичне (тілесне), когнітивне (психічне), соціальне, емоційне, психологічне, духовне, матеріальне;

по-друге, трактування загальновизнаного поняття «здоров'я» (ВОO3) передбачає стан повного фізичного, духовного та соціального благополуччя; правильна, нормальна діяльність організму, його повне фізичне та психічне благополуччя. Обидва визначення вказують на циклічну єдність;

по-трете, обидва поняття часто трактують як основу позитивного функціонування особистості в соціумі;

по-четверте, спорідненістю підсилюють протилежні до понять «здоров'я» та «благополуччя» - поняття - «хвороба» та «неблагополуччя»;

по-п'яте, обидва феномени мають спільні фактори: біологічний (генетика, стать, конституція тіла), соматичні чинники (хвороби); екологічний (географічні та кліматичні умови); соціально-економічний (зайнятість батьків, дисгармонія сімейних відносин та виховання, порушення в сфері дитячо-батьківських відносин та ін.); психологічний (характер, темперамент дитини та ін.);

по-шосте: пряма залежність здатності до адаптації від рівня здоров'я та благополуччя людини;

по-сьоме: благополуччя є проявом здоров'я, а останнє, у свою чергу, є ознакою, від якої залежить якість життя людини, тобто іiі благополуччя [1, с. 332- 339].

Л. Куліков проводить паралель взаємозв'язку психічного здоров'я з благополуччям, зазначаючи, що психічне здоров'я - це не лише адекватність і цілеспрямованість поведінки, діяльності, послідовність у діях і вчинках, а й разом 3 тим - злагодженість у протіканні багатьох процесів, i, звичайно, переживання благополуччя, задоволеності життям. повноцінний розвиток і злагоджена робота всіх психічних функцій, стан душевного благополуччя, який характеризується відсутністю хворобливих психічних проявів, що забезпечує адекватну до умов навколишньої дійсності регуляцію поведінки та діяльності.

Отже, психологічне здоров'я - це стан душевного благополуччя (комфорту), адекватного ставлення людини до навколишнього світу, відсутність хворобливих психічних явищ (фобій, неврозів), що є необхідною умовою іiі повноцінного розвитку. Психологічно здорова людина розумна, відкрита до співпраці, захищена від ударів життя і озброєна необхідним 
інструментарієм, щоб справлятися 3 життєвими викликами. Благополуччя створює передумови для усвідомлення своїх можливостей, формування позитивного образу «Яконцепції», набуття здатності до саморегуляції психічних станів, розвитку самосвідомості, рефлексії, здійснення в подальшому суб `ктивної оцінки власного життя.

Поняття «здоров'я» та «благополуччя» близькі за змістом, проте не тотожні; «здоров'я» - вужче, а «благополуччя» включає ширшу наповнюваність змісту. Зрозуміло що людина, яка є фізично або психічно хворою, зазвичай, має нижчі шанси почувати себе благополучною, ніж здорова у всіх відношеннях. Водночас, є безліч прикладів, які підтверджують і явно демонструють, що люди з фізичними чи незначними психічними відхиленнями відчувають себе абсолютно благополучними, щасливими.

\section{Перелік використаних джерел:}

1. Галецьька I. Психологічне здоров'я / I. Галецька, Т. Сосновський // Психологія здоров'я: теорія і практика. Львів: - Видавничий центр ЛНУ імені Івана Франка, 2006. - С. 89-122.

2. Коробка Л. Психологічне здоров'я людини в контексті здорового способу життя / Л. Коробка // Український науковий журнал «Освіта регіону» - 2011. - №2. - C. 332-339.

3. Коцан I. Психологія здоров'я людини / І. Коцан, Г. Ложкін, М. Мушкевич // За ред. І. Коцана. - Луцьк: PBВ «Вежа» Волин. нац. ун-ту ім. Лесі Українки, 2009.- 316 с.
4. Репина Н. Основы клинической психологии / Н. Репина, Д. Воронцов, И. Юматова // Ростов-н/Д.: Феникс, 2003. $-214 \mathrm{c}$

5. Шевеленкова T. Психологическое благополучие личности (обзор основных концепций и методика исследования) / Т. Шевеленкова, П. Фесенко // Психологическая диагностика.- Обнинск : Психологический институт РАO. -2005. - № 3. - С. 95-129.

6. Compton $W$. Toward a tripartite factor structure of mental health: subjective well-being, personal growth, and religiosity / W. Compton // The Journal of Psychology. 2001. - № 5. - Vol. 135. - P. 486-500.

7. Vitters $J$. Subjective well-being versus self-actualization: Using the flow-simplex to promote a conceptual clarification of subjective quality of life / J. Vitters // Social Indicators Research. - 2004. - № 3. - Vol. 65. - P. 299331.

\section{References (Transliteration):}

1.Haletska I. Psykholohichne zdorovia / I. Haletska, T. Sosnovskyi // Psykholohiia zdorovia: teoriia i praktyka. Lviv: Vydavnychyi tsentr LNU imeni Ivana Franka, 2006. - S. 89 -122 .

2. Korobka L. Psykholohichne zdorovia liudyny v konteksti zdorovoho sposobu zhyttia / L. Korobka // Ukrainskyi naukovyi zhurnal «Osvita rehionu» - 2011. - №2. - S. 332 -339 .

3. Kotsan I. Psykholohiia zdorovia liudyny / I. Kotsan, H. Lozhkin, M. Mushkevych // Za red. I. Kotsan. - Lutsk: RVV "Vezha” Volyn. nats. un-tu im. Lesi Ukrainky, 2009. $-316 \mathrm{~s}$.

4. Repina N. Osnovy klinicheskoy psikhologii / N. Repina, D. Vorontsov, I. Yumatova // Rostov-n/D.: Feniks, 2003. $-214 \mathrm{~s}$.

5. Shevelenkova T. D. Psihologicheskoe blagopoluchie lichnosti (obzor osnovnyh koncepciy i metodika issledovaniya) / T. D. SHevelenkova,P. Fesenko // Psihologicheskaya diagnostika. - Obninsk : Psihologicheskiy institut RAO. 2005. - № 3. - S. 95-129. 
6. Compton $W$. Toward a tripartite factor structure of mental health: subjective well-being, personal growth, and religiosity / W. Compton // The Journal of Psychology. 2001. - № 5. - Vol. 135. - P. 486-500.

7. Vitters $J$. Subjective well-being versus self-actualization: Using the flow-simplex to promote a conceptual clarification of subjective quality of life / J. Vitters // Social Indicators Research. - 2004. - № 3. - Vol. 65. - P. 299331.

\section{Kashlyuk Yulianna}

Ph.D. student in psychological department of faculty of philosophy at Ivan Franko National University of Lviv, Lviv (Ukraine)

\section{PSYCHOLOGICAL HEALTH AND PSYCHOLOGICAL WELL-BEING OF THE INDIVIDUAL AS A COMPONENT OF SATISFACTION WITH LIFE}

\section{ABSTRACT}

In the article was investigated and analyzed psychological health and psychological well-being of the individual in the spectrum of theoretical and methodological approaches to this problem. Based on the analysis of foreign and domestic psychological literature were offered: two-factor structure of psychological health (structural and procedural psychological health and psychological health, and mental health); three levels of psychological health according to the levels of psychological functioning system (personal-semantic level, level of individual and psychological health, level of psychophysical health); criteria of psychological health (specific of the individual, mental conditions, mental processes); model of psychological health (axiological component, instrumental component, needs - motivation component, developing component, sociocultural component).

Analyzing the model of psychological health, we can affirm that a person takes full responsibility for its life, understands and interacts with others, accepts itself and, in the same time, recognizes the value and uniqueness of the other people.

It was established similarities in the interpretation of the concepts of «health» and «well-being», in particular «psychological wellbeing» of the individual is identified with a number of close to the meaning of «mental health», «positive lifestyle», «emotional comfort», «quality of life», «satisfaction with life».

These concepts are often associated with the term «psychological health». It was established that given concept is multifactorial construction, which is a complex of interrelation of cultural, social, psychological, physical, economical, and spiritual factors affected by genetic predisposition, environment and features of individual development. Thus, both approaches are often interpreted as a base of positive functioning of the individual in the society. Personality is explored in the terms of its active life position, in the meaning, that the ability to self-actualization, self-realization of their own choice, availability goals, and so on.

Theoretical and methodological analysis of the literature gave a chance to confirm the relationship of psychological health and 
psychological well-being in the context of subjective quality of life and satisfaction with life.

Keywords: health, psychological health, psychological well-being, criteria of psychological health, satisfaction with life.

\section{Каилюк Юлианна Игоревна}

Аспирант кафедры психологии философского факультета Львовского национального университета имени И. Я. Франка, г. Львов (Украина)

\section{ПСИХОЛОГИЧЕСКОЕ ЗДОРОВЬЕ И ПСИХОЛОГИЧЕСКОЕ БЛАГОПОЛУЧИЕ ЛИЧНОСТИ КАК СОСТАВЛЯЮЩИЕ УДОВЛЕТВОРЕННОСТИ ЖИЗНЬЮ}

Аннотация. В статье исследованы и проанализированы психологическое здоровье и психологическое благополучие личности с точки зрения теоретико-методологических подходов к данной проблематике. Основываясь на анализе иностранной и отечественной психологической литературы предложено: двухфакторную структуру психического здоровья (структурно-процессуальное психическое здоровье и отдельно- психологическое здоровье) три уровня психического здоровья в соответствии с уровнями функционирования психического аппарата (личностно-смысловой уровень, уровень индивидуальнопсихологического здоровья, уровень психофизиологического здоровья); критерии психического здоровья (свойства личности, психические состояния, психические процессы); модель психологического здоровья (аксиологический компонент, инструментальный компонент, потребностно - мотивационный компонент, развивающий компонент, социокультурный компонент).

Анализируя модель психологического здоровья, можно утверждать, что человек полностью принимает ответственность за свою жизнь, понимает и взаимодействует с другими людьми, принимает самого себя и при этом признает ценность и уникальность окружающих людей.

Установлено сходство в трактовке понятий «здоровье» и «благополучие», в частности «психологическое благополучие» личности характеризуют с целым рядом близких по значению понятий: «психическое здоровье», «положительный образ жизни», «эмоциональный комфорт», «качество жизни», «удовлетворенность жизнью».

Чаще всего указанные понятия ассоциируются с понятием «психологическое здоровье». Установлено, что данное понятие это многофакторный конструкт, представляет собой сложную взаимосвязь культурных, социальных, психологических, физических, экономических, духовных факторов и зависит от влияния генетической предрасположенности, среды и особенностей индивидуального развития. Таким образом, оба понятия часто описывают как основу положительного функционирования личности в социуме. Личность же рассматривается с точки зрения ее активной жизненной позиции, то есть, способности к 
самоактуализации, саморазвитию, осуществлению собственного выбора, наличия целей и т.Д..

Теоретико-методологический анализ литературы позволил подтвердить взаимосвязь психологического здоровья и психологического благополучия с точки зрения субъективного качества жизни, удовлетворенностью жизни.

Ключевые слова: здоровье, психологическое здоровье, психологическое благополучие, критерии психологического здоровья, здоровый образ жизни. 